\title{
Engineering cocrystals of paliperidone with enhanced solubility and dissolution characteristics
}

\author{
Earle Radha Rani ${ }^{1,2} *$, Gadela Venkata Radha ${ }^{2}$ \\ ${ }^{1}$ Maharajah's College of Pharmacy, Vizianagaram, Andhra Pradesh, India -535002 \\ ${ }^{2}$ GITAM Institute of Pharmacy, GITAM Deemed to be University, Visakhapatnam, \\ Andhra Pradesh, India - 535002
}

*Corresponding author: Earle Radha Rani, E-mail: radhaearle@yahoo.com

\begin{abstract}
In the present study, co-crystals (CCs) of Paliperidone (PPD) with coformers like benzoic acid (BA) and P-amino benzoic acid (PABA) were synthesized and characterized to improve the physicochemical properties and dissolution rate. CCs were prepared by the solvent evaporation (SE) technique and were compared with the products formed by neat grinding (NG) and liquid assisted grinding (LAG) in their enhancement of solubility. The formation of CCs was confirmed by the IR spectroscopy, powder X-ray diffraction and thermal analysis methods. The saturation solubility studies indicate that the aqueous solubility of PPD-BA and PPD-PABA CCs was significantly improved to $1.343 \pm 0.162 \mathrm{mg} / \mathrm{ml}$ and $1.964 \pm 0.452 \mathrm{mg} / \mathrm{ml}$, respectively, in comparison with the PPD solubility of $0.473 \mathrm{mg} / \mathrm{ml}$. This increase in solubility is 2.83 - and 3.09fold, respectively. PPD exhibited a poor dissolution of $37.8 \%$ in $60 \mathrm{~min}$, while the dissolution of the CCs improved tremendously to $96.07 \%$ and $89.65 \%$ in $60 \mathrm{~min}$. CCs of PPD with BA and PABA present a novel approach to overcome the solubility challenges of poorly water-soluble drug PPD.
\end{abstract}

Keywords: Paliperidone, cocrystal, coformer, solubility, dissolution

doi.org/10.5937/arhfarm71-32997 


\section{INTRODUCTION}

One of the significant challenges the pharmaceutical industry faces today is the development of drugs with required aqueous solubility (1). As poorly aqueous soluble drugs exhibit low dissolution in biological fluids, they are insufficiently absorbed into the human body (2). With the advent of crystal engineering technology, pharmaceutical cocrystals that exhibit improved physicochemical and mechanical properties have emerged as a potential alternative $(3,4)$. In recent years, pharmaceutical cocrystals have been promising techniques in modulating the physicochemical properties of drugs and thus aiding in enhancing the solubility of Biopharmaceutical Classification System (BCS) class II and IV drugs (5). A pharmaceutical cocrystal is a multicomponent system which is structurally homogeneous, comprising two or more components in stoichiometric ratios, including an ionic or a molecular active pharmaceutical ingredient $(6,7)$. The possible association occurring between the drug and the coformers is through weak interactions like hydrogen bonds (8). The functional groups commonly responsible for hydrogen bond formation are carboxylic acid, amide and alcohol groups (9). A supramolecular homosynthon is an association of identical functional groups, while heterosynthon is made of two different functional groups (10). Cocrystals could offer potential advantages of improved solubility, dissolution, bioavailability and synergistic/ additive effects of the components (11).

Paliperidone is chemically 3-\{2-[4-(6-fluoro-1,2-benzoxazol-3-yl) piperidin-1-yl] ethyl \}-9- hydroxy-2-methyl-6,7,8,9- tetrahydropyrido [1,2-a] pyrimidin-4-one. It is a second-generation atypical antipsychotic agent used for the treatment of schizophrenia. The oral bioavailability of the drug is $28 \%$, due to its poor water solubility. Various attempts have been made to enhance the dissolution of the drug by formulating SEDDS (12), nanocrystals (13), co-ground mixtures (14), liquisolid technology (15), solid dispersions (16), spray drying (17), hot melt extrusion (18), and co-crystals (19).

In the present investigation, cocrystals of paliperidone were developed using benzoic acid (BA) and 4-amino benzoic acid (PABA) as coformers by the solvent evaporation technique. Structural characterization of the cocrystals was performed by Fourier Transform Infrared spectroscopy (FTIR), Differential Scanning Calorimetry (DSC), powder X-Ray diffraction studies (PXRD) and Scanning Electron Microscopy (SEM). The CCs were also evaluated through saturation solubility studies, micromeritic studies and in vitro drug dissolution (20). 
<smiles>Cc1nc2n(c(=O)c1CCN1CCC(c3noc4cc(F)ccc34)CC1)CCCC2O</smiles>

(A)
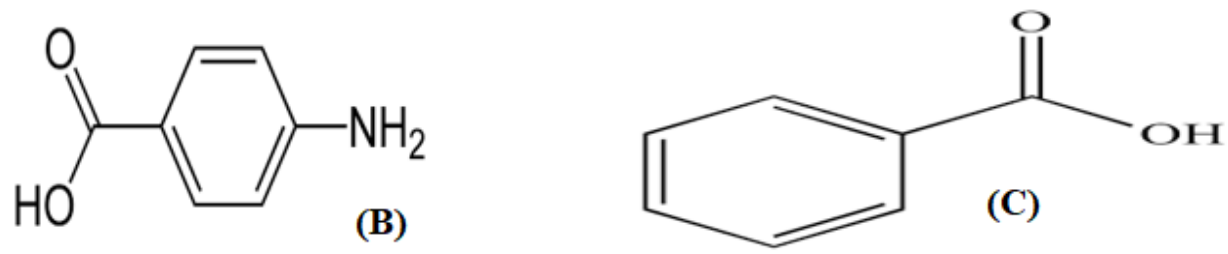

Figure 1. Molecular structures of (A)- Paliperidone; (B)- 4-Amino benzoic acid (PABA); (C)- Benzoic acid

Slika1. Strukturne formule (A) paliperidona; (B) 4-aminobenzojeve kiseline (PABA); (C) benzojeve kiseline

\section{EXPERIMENTAL SECTION}

\section{Materials}

Paliperidone was obtained as a gift sample from MSN laboratories, Hyderabad. Para amino benzoic acid and benzoic acid were procured from Finar chemicals Limited, Ahmedabad. Dichloromethane and hydrochloric acid were purchased from Thermo Fisher Scientific India Pvt Ltd.

\section{Design of cocrystals of PLP}

The formation of cocrystals occurs due to possible intermolecular interactions between the drug and the coformers through hydrogen bonding. Paliperidone is a benzisoxazole derivative possessing 1 hydrogen bond donor group (-OH) and 7 hydrogen bond acceptor groups ( $4 \mathrm{~N}$ atoms, $2 \mathrm{O}$ atoms and $1 \mathrm{~F}$ atom). As for the coformers used, BA possesses 1 hydrogen bond donor group and 2 hydrogen bond acceptor groups and PABA has 2 hydrogen bond donor groups and 3 hydrogen bond acceptor groups. These groups may be responsible for the probable formation of hydrogen bonds (21). 


\section{Synthesis of cocrystals}

\section{Synthesis of physical mixtures by neat grinding (NG)}

PPD (1 $\mathrm{mmol})$ and coformers PABA $(1 \mathrm{mmol})$ and BA $(1 \mathrm{mmol})$ were ground for $30 \mathrm{~min}$ in a mortar and pestle using the neat grinding (NG) technique. The product obtained was stored in a desiccator until further use (22).

\section{Synthesis by liquid assisted grinding (LAG)}

PPD (1mmol) with PABA (1mmol) and BA (1mmol) were ground for 30min using DCM as a solvent. The obtained powder was vacuum dried at $40^{\circ} \mathrm{C}$ for $24 \mathrm{~h}$ and stored at room temperature until further use (23).

\section{Synthesis by solvent evaporation (SE)}

The drug and coformer in equimolar ratios (1 $\mathrm{mmol}$ each) were dissolved in $10 \mathrm{ml}$ of DCM using sonication for 30min. The obtained product was sealed with aluminium foil, which was perforated to allow the solvent to evaporate slowly under room temperature, in order to obtain the cocrystals (24).

\section{Characterization of PPD cocrystals}

\section{Saturation solubility studies}

Saturation solubility studies were performed for the pure drug and products obtained by NG, LAG and SE by adding them in excess quantity into vials comprising $10 \mathrm{ml}$ distilled water and $0.1 \mathrm{~N} \mathrm{HCl}$ separately. The capped vials were placed in a water bath shaker at room temperature for $24 \mathrm{~h}$ to attain equilibrium. The supernatant was filtered through Whatman filter paper. The filtrate was diluted by considering $1 \mathrm{ml}$ of filtrate and making it up to $10 \mathrm{ml}$ with the respective solvents. The solutions were analysed spectrophotometrically at $275 \mathrm{~nm}$ to determine the concentration of the drug. All the studies were conducted in triplicate.

\section{FTIR studies}

FTIR study of all the samples were performed on the FTIR Agilent Cary 630 series. Around 1-2mg of sample was directly placed on the diamond ATR and scanned from $4000-400 \mathrm{~cm}^{-1}$. The peaks obtained were interpreted to study the formation of CCs (25).

\section{Differential Scanning Calorimetry (DSC)}

Thermal analyses of the samples were carried out by placing 1-3mg of sample in crimped sealed aluminium pans and scanned from $50-350{ }^{\circ} \mathrm{C}$ at a heating rate of 10 ${ }^{\circ} \mathrm{C} / \mathrm{min}$ under continuously purged nitrogen flow rate of $50 \mathrm{ml} / \mathrm{min}(26,27)$. 


\section{Powder X-Ray Diffraction studies (PXRD)}

For analysing the samples through PXRD studies, all the samples were irradiated with $\mathrm{Cu} \mathrm{K \alpha}, 40 \mathrm{kV}, 40 \mathrm{~mA}$. Data were collected at room temperature over an angular range of $2^{\circ}$ to $40^{\circ} 2 \Theta$ value in continuous scan mode at a scan rate of $5^{\circ} / \mathrm{min}$ (28).

\section{Scanning Electron Microscopy (SEM)}

The surface topography of the formed CCs was characterized using SEM. The samples were mounted on an aluminium stub and coated with a thin gold layer. The analysis was performed using JSM 6360, Joel, which was operated at $10 \mathrm{kV}$ acceleration voltage (29).

\section{Evaluation of micromeritic properties}

The obtained CCs were characterized for various micromeritic properties like bulk density, tapped density, Hausner's ratio, Carr's compressibility index and angle of repose because these properties are influenced by particle size, shape and surface texture $(30,31)$. The following equations were used in the calculation of these properties:

$$
\begin{gathered}
\text { Hausner's ratio }=\frac{\text { Tapped density }}{\text { Bulk density }} \\
\text { Carr's compressibility index }=\frac{\text { Tapped density }- \text { Bulk density }}{\text { Tapped density }} * 100 \\
\text { Angle of repose } \theta=\tan ^{-1} \frac{\mathrm{h}}{\mathrm{r}}
\end{gathered}
$$

\section{Determination of percentage yield}

The percentage yield of the product was calculated considering the weight of the formed CCs and the initial weight of the drug and coformer taken (32).

$$
\text { Percentage yield }=\frac{\text { Weight of the cocrystal formed }}{\text { Total weight of drug and coformer taken }} * 100
$$

\section{Estimation of drug content}

The prepared CCs by SE were dissolved in $100 \mathrm{ml}$ of $0.1 \mathrm{~N} \mathrm{HCl}$ in weights equivalent to $10 \mathrm{mg}$ of drug. The solutions were filtered through a Whatman filter paper. $10 \mathrm{ml}$ of the filtrate was taken and diluted to $100 \mathrm{ml}$. The absorbance was measured at $275 \mathrm{~nm}$ and the concentration was calculated (33).

\section{In vitro dissolution studies}

In vitro drug release was studied using a USP type II dissolution apparatus. Drug and CCs prepared by SE were considered equivalent to a $6 \mathrm{mg}$ dose and placed into 
$900 \mathrm{ml}$ of $0.1 \mathrm{~N} \mathrm{HCl}$. The entire study was carried out at a temperature of $37 \pm 0.5{ }^{\circ} \mathrm{C}$, paddle rotation speed of $50 \mathrm{rpm}$ for a time period of $60 \mathrm{~min}$. $5 \mathrm{ml}$ aliquots were withdrawn at 5, 10, 15, 30, 45 and 60min time intervals, filtered, diluted 10times and analysed using a UV-Vis spectrophotometer. The quantity of the sample removed was replaced with an equal quantity of fresh dissolution medium. All the experiments were conducted in triplicate (34).

\section{RESULTS}

\section{Saturation solubility studies}

Solubility analysis was conducted both in distilled water and $0.1 \mathrm{~N} \mathrm{HCl}$. The solubility of pure drug was $0.473 \mathrm{mg} / \mathrm{ml}$ and $0.788 \pm 0.022 \mathrm{mg} / \mathrm{ml}$ respectively in distilled water and $0.1 \mathrm{~N} \mathrm{HCl}$. The products obtained by NG and LAG exhibited solubilities that were slightly higher, while those prepared using the SE technique exhibited significantly increased solubilities compared with the pure drug. The aqueous solubilities of PPD-PABA CCs and PPD-BA CCs obtained by SE were enhanced by 3.09 - fold $(1.964 \pm 0.452 \mathrm{mg} / \mathrm{ml})$ and 2.83 - fold $(1.343 \pm 0.162 \mathrm{mg} / \mathrm{ml})$ respectively. CCs of PABA prepared using the SE technique exhibited an increase in 3.88- fold $(3.064 \pm 0.864 \mathrm{mg} / \mathrm{ml})$ and that of BA CCs was an increase in 2.87-fold $(2.565 \pm 0.013 \mathrm{mg} / \mathrm{ml})$ in $0.1 \mathrm{~N} \mathrm{HCl}$. This tremendous increase in solubility may be due to the formation of CCs from the SE technique. (35).

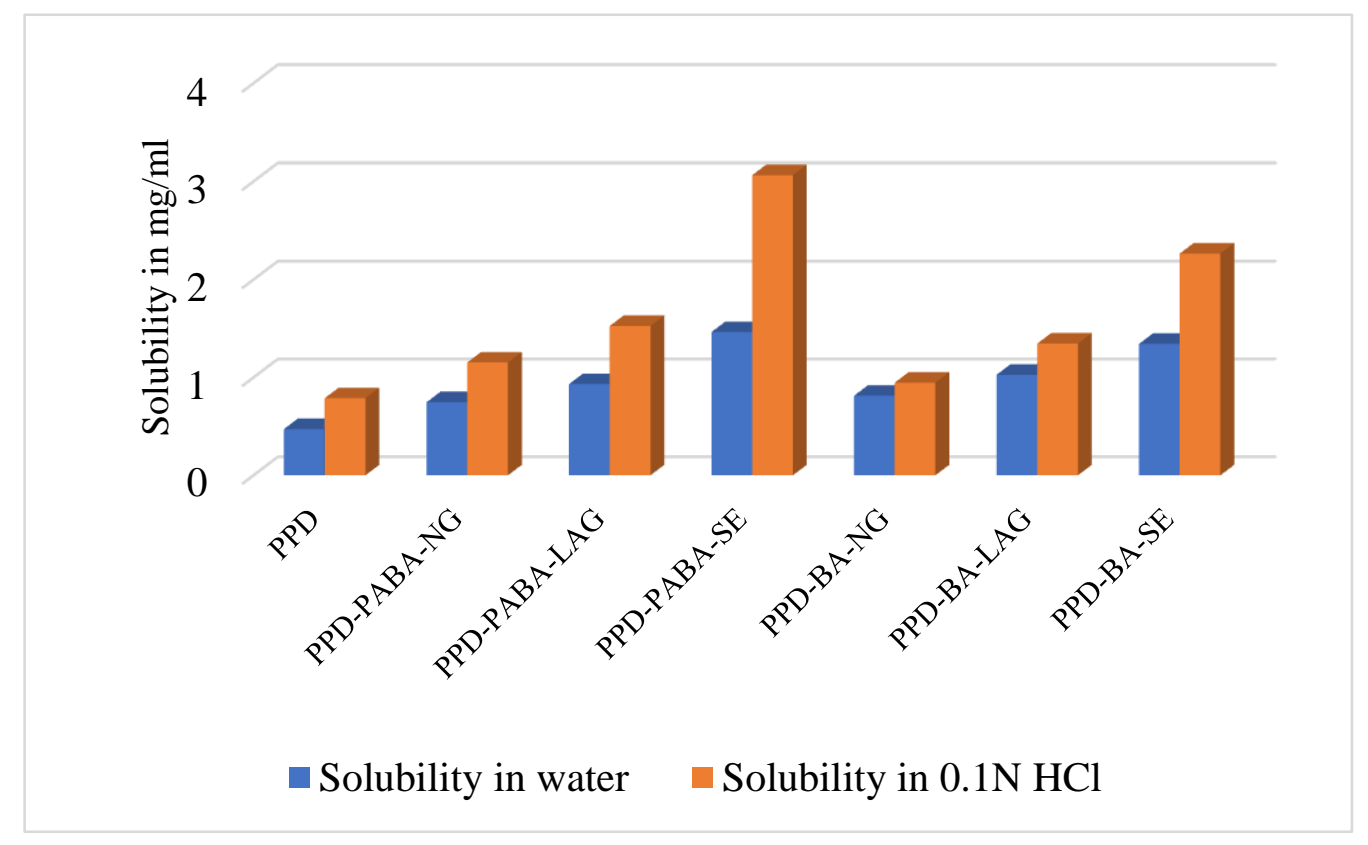

Figure 2. Saturation solubility studies of PPD, PPD-PABA obtained by NG, LAG, SE; PPD-BA obtained by NG, LAG and SE

Slika 2. Ispitivanje rastvorljivosti PPD, PPD-PABA dobijenih postupcima NG, LAG, SE; PPD-BA dobijenog postupcima NG, LAG i SE 


\section{Fourier Transform Infrared Spectroscopy}

FTIR analysis helps to interpret the molecular interactions. The FTIR spectra of the parent drug molecule, coformers and the formed cocrystals are manifested in Fig. 2. The characteristic FTIR bands of PPD are as follows: $1144.3 \mathrm{~cm}^{-1}$ (C-F stretching), $3276.3 \mathrm{~cm}^{-1}$ (O-H stretching), $1340.0 \mathrm{~cm}^{-1}$ (C-N stretching), $1619.5 \mathrm{~cm}^{-1} \quad(\mathrm{C}=\mathrm{O}$ carbonyl). PABA exhibited characteristic bands at $3360.2 \mathrm{~cm}^{-1}\left(-\mathrm{NH}_{2}\right.$ symmetric stretching), $1658.7 \mathrm{~cm}^{-1}$ (C=O stretching), $1343.7 \mathrm{~cm}^{-1}$ (-CN stretching), $1284.1 \mathrm{~cm}^{-1}$ (C$\mathrm{OH}$ stretching). BA showed intensive bands at $1679.2 \mathrm{~cm}^{-1}(\mathrm{C}=\mathrm{O}$ stretching), 1287.8 $\mathrm{cm}^{-1}$ (C-OH stretching). The data are as per those reported in the literature (26).

The FTIR spectra of PPD with coformers displayed a significant shift in few band positions. In the spectrum of PPD-PABA cocrystals, the shifts occurred in the stretching bonds of $\mathrm{O}-\mathrm{H}$ from $3276.3 \mathrm{~cm}^{-1}$ to $3334.1 \mathrm{~cm}^{-1}, \mathrm{C}=\mathrm{O}$ from $1619.5 \mathrm{~cm}^{-1}$ to $1630.7 \mathrm{~cm}^{-1}$. In the spectrum of PPD-BA, the shift occurred in the stretching bond of $\mathrm{C}=\mathrm{O}$ to 1647.5 $\mathrm{cm}^{-1}$. These shifts are evident in the ranges assigned to hydroxyl group and carbonyl group of the coformers. The shifts in the wavenumbers may be interpreted as the interaction of carbonyl group and hydroxyl group of BA, carbonyl, hydroxyl and amine group of PABA with the carbonyl group and nitrogen group of PPD $(37,38)$.

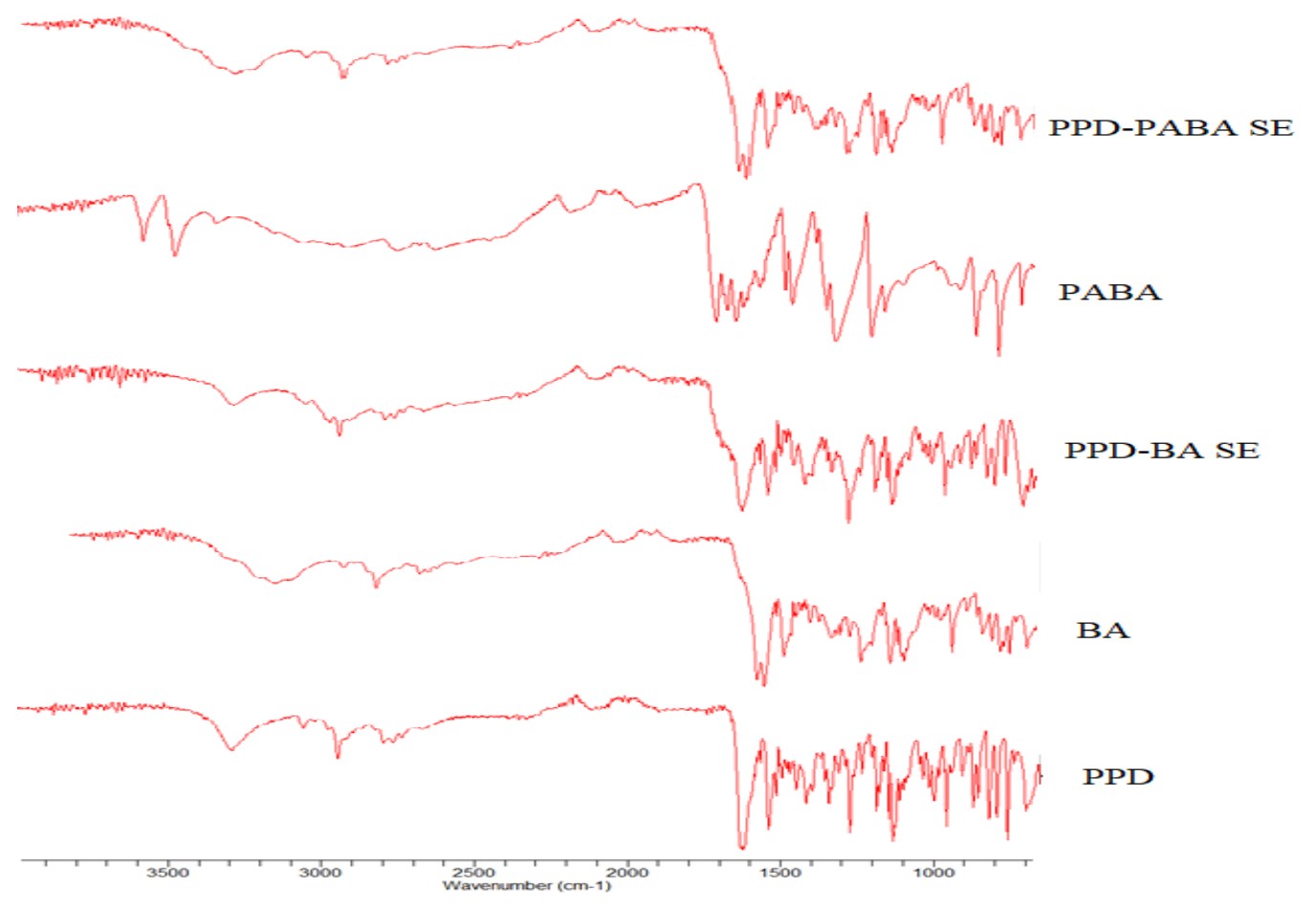

Figure 3. FTIR spectra of PPD, coformers BA and PABA; PPD-BA and PPD-PABA CCs obtained by SE

Slika 3. FTIR spektri PPD, koformera BA i PABA; kokristala PPD-BA i PPDPABA dobijenih postupkom SE 


\section{Differential Scanning Calorimetry}

The DSC thermogram of PPD exhibited a sharp endothermic peak, representing its melting point at $173.87^{\circ} \mathrm{C}$. The cocrystals of PPD with PABA and BA prepared by the SE technique exhibited single endothermic peaks at $105{ }^{\circ} \mathrm{C}$ and $101{ }^{\circ} \mathrm{C}$ respectively, indicating a homogeneous solid phase. The melting point of both CCs was different from that of drug $\left(173.87{ }^{\circ} \mathrm{C}\right)$ and the coformers (PABA $187^{\circ} \mathrm{C}$; BA $\left.122.3^{\circ} \mathrm{C}\right)$. The thermogram of CCs, showed that the corresponding peaks of PPD, PABA, BA were absent and instead new sharp peaks appeared concluding the crystallization of drug with the coformers (39).

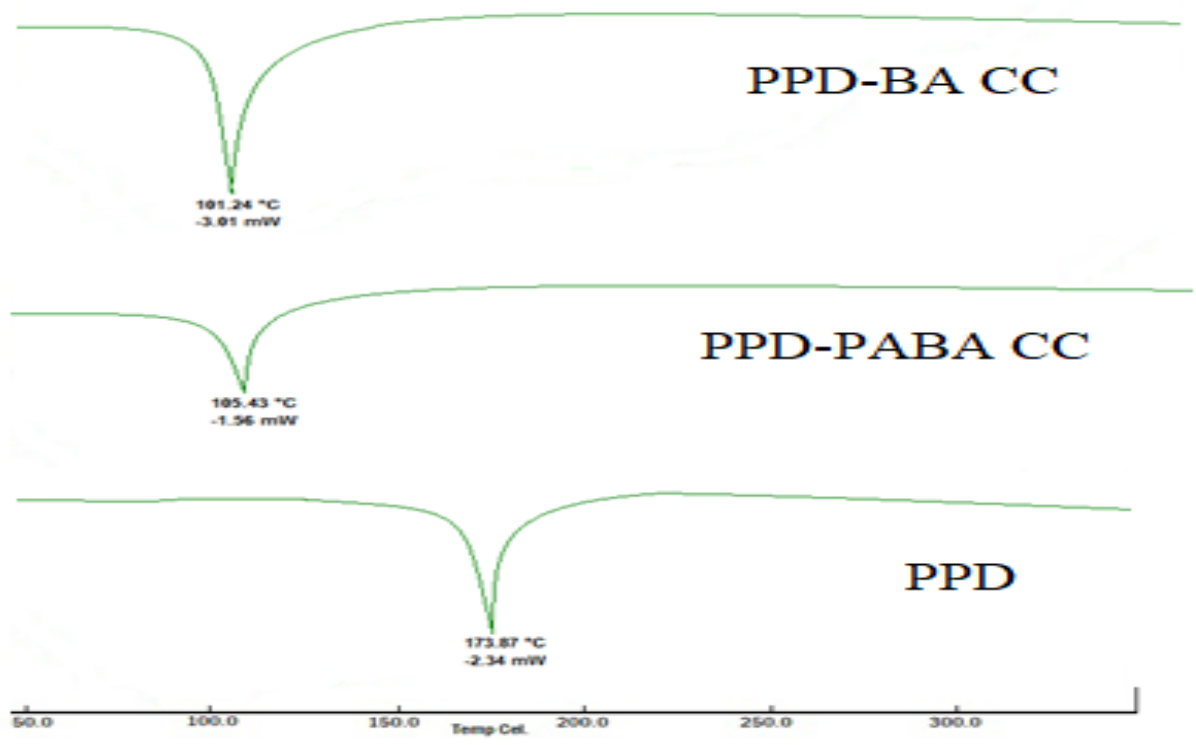

Figure 4. DSC thermogram of PPD, PPD-BA and PPD-PABA CCs obtained by SE

Slika 4. DSC termogram kokristala PPD, PPD-BA i PPD-PABA dobijenih postupkom SE

\section{Powder X-Ray Diffraction studies}

The XRD spectrum of PPD showed characteristic peaks on $2 \Theta$ angle position at $15.878^{\circ}, 19.056^{\circ}, 22.945^{\circ}, 25.076^{\circ}, 27.113^{\circ}$ and $32.078^{\circ}$ respectively. While the XRD spectrum of PPD- PABA CC exhibited peaks at $15.564^{\circ}, 19.048^{\circ}, 22.875^{\circ}, 25.116^{\circ}$, $27.115^{\circ}$, the XRD spectrum of PPD-BA CC exhibited peaks at $15.756^{\circ}, 19.052^{\circ}$, $22.913^{\circ}, 25.1129^{\circ}, 27.124^{\circ}(40)$. The XRD pattern of pure drug had a greater number of peaks when compared to the CCs. The difference in relative intensities may be attributed to the differences in crystal size and crystal habits (41). 


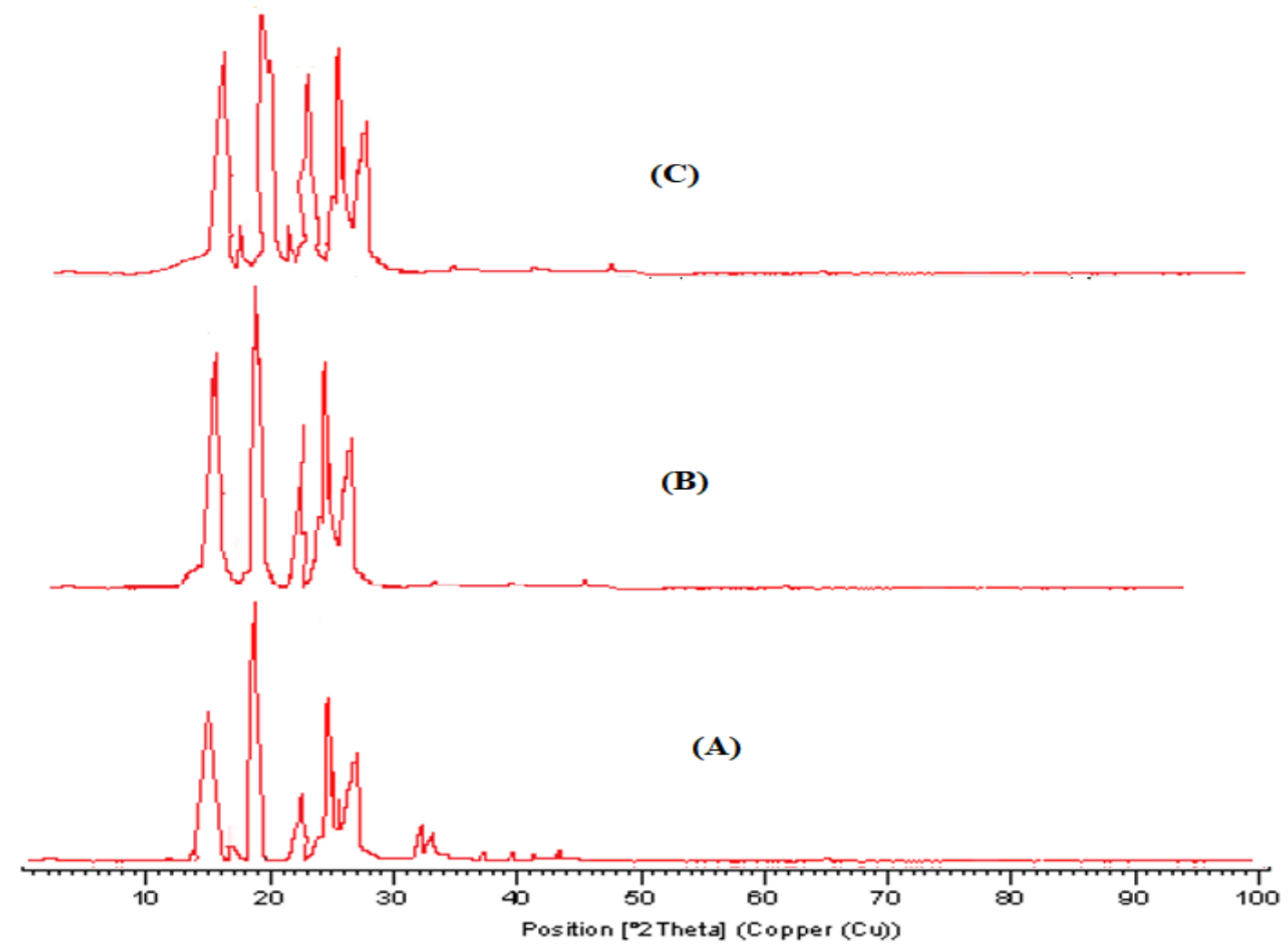

Figure 5. XRD spectrum of PPD, PPD-BA and PPD-PABA CCs obtained by SE

Slika 5. XRD spektar kokristala PPD, PPD-BA i PPD-PABA dobijenih postupkom SE

\section{Scanning Electron Microscopy}

SEM images of PPD and CCs formed from SE technique were presented in Fig.6. SEM analysis revealed a difference in the surface topology of the CCs when compared to that of the pure drug. It was observed that pure PPD exhibited irregularly shaped particles in various sizes. The morphology of PPD-PABA CCs appeared to be slender, elongated needle like crystals. While that of PPD-BA exhibited short, broad, plate like particles. SEM images of both CCs were found to be different from those of the pure drug indicating a change in the morphology of the CCs $(42,43)$. 


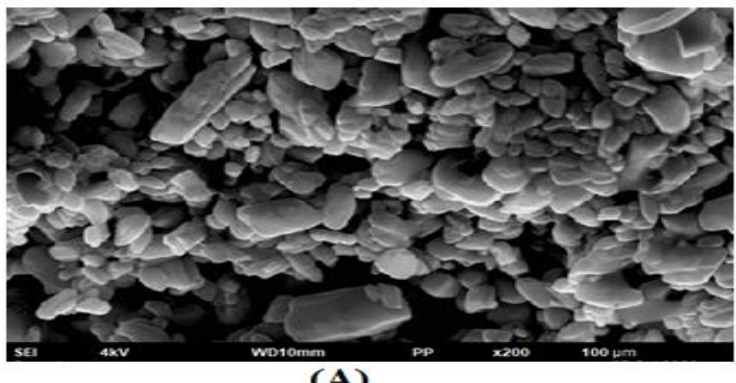

(A)

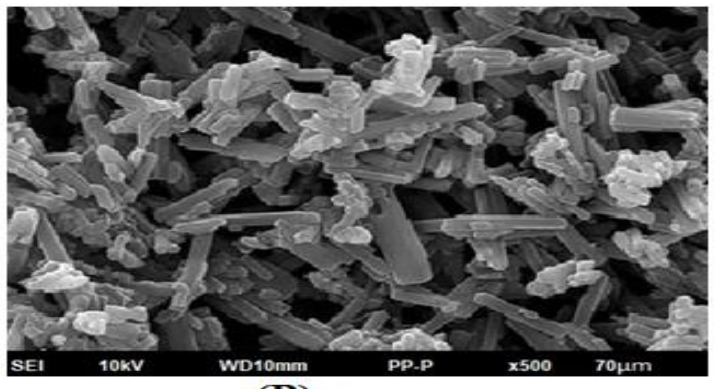

(B)

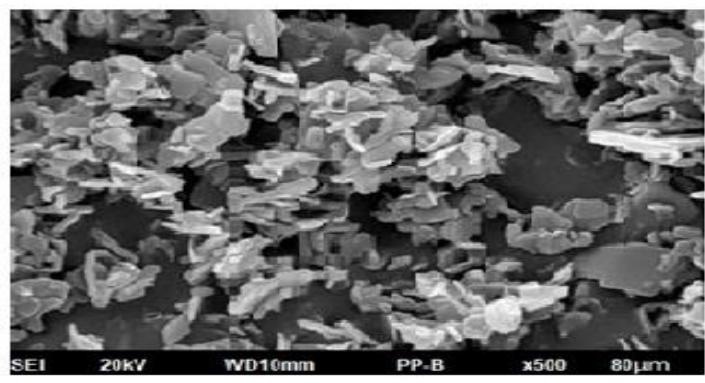

(C)

Figure 6.SEM images of (A)- PPD; (B)- PPD-PABA CC obtained from SE;

(C)- PPD-BA CC obtained from SE

Slika 6. SEM mikrografije (A) PPD; (B) PPD-PABA kokristala dobijenih postupkom SE; (C) PPD-BA kokristala dobijenih postupkom SE

\section{Evaluation of micromeritic properties}

The micromeritic properties of the CCs as shown in Table I were found to be lowered in comparison with that of the pure drug, indicating an improved flow.

Table I Flow properties co-crystals

Tabela I Protočnost kokristala

\begin{tabular}{|c|c|c|c|c|c|}
\hline Components & $\begin{array}{c}\text { Angle of } \\
\text { repose }\end{array}$ & $\begin{array}{c}\text { Bulk density } \\
\left(\mathbf{g} / \mathbf{c m}^{\mathbf{3}}\right)\end{array}$ & $\begin{array}{c}\text { Tapped density } \\
\left(\mathbf{g} / \mathbf{c m}^{\mathbf{3}}\right)\end{array}$ & $\begin{array}{c}\text { Hausner's } \\
\text { ratio }\end{array}$ & Carr's index \\
\hline PPD & $31.07 \pm 0.21$ & $0.39 \pm 0.49$ & $0.49 \pm 0.74$ & $1.25 \pm 0.17$ & $20.40 \pm 0.09$ \\
\hline PPD-BA CC & $26.05 \pm 0.96$ & $0.46 \pm 0.73$ & $0.53 \pm 1.56$ & $1.15 \pm 0.83$ & $13.20 \pm 0.12$ \\
\hline PPD-PABA CC & $27.64 \pm 0.99$ & $0.51 \pm 0.76$ & $0.57 \pm 0.21$ & $1.11 \pm 0.82$ & $10.52 \pm 0.41$ \\
\hline
\end{tabular}

(Values expressed as mean \pm standard deviation, $\mathrm{n}=3$ ) 


\section{Determination of percentage yield and estimation of drug content}

The percentage yield of the CCs formed between PPD-BA and PPD-PABA was $93.89 \pm 0.56 \%$ and $95.1 \pm 1.23 \%$ respectively. The drug content of the PPD-BA and PPDPABA CCs was $98.04 \pm 1.84 \%$ and $98.72 \pm 0.41 \%$ respectively.

\section{In vitro drug dissolution studies}

The dissolution profiles of the drug and the CCs were shown in Fig. 7. They clearly indicated that drug had poor dissolution, and an increase in dissolution of the drug was observed in formulations prepared using NG, LAG as well as in the CCs ${ }^{44}$. PPD exhibited a dissolution of $37.80 \pm 0.56 \%$ in $60 \mathrm{~min}$, while the CCs of PABA and BA showed $96.07 \pm 0.67 \%$ and $89.65 \pm 1.95 \%$ respectively in $60 \mathrm{~min}$. This enhancement in dissolution may be due to CCs formation between the drug and coformers that alter the physicochemical properties.

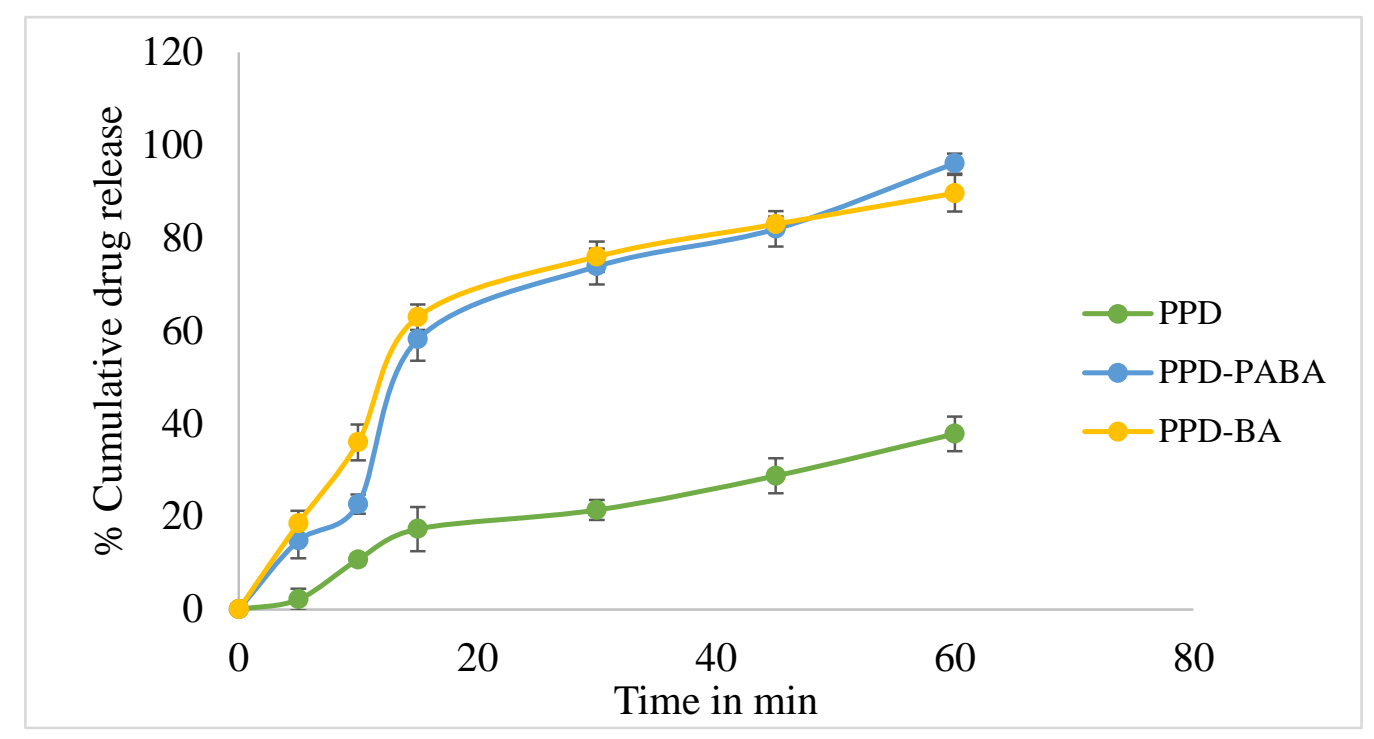

Figure 7. Dissolution data of drug and CCs

Slika 7. Profili brzine rastvaranja lekovite supstance i kokristala

\section{DISCUSSION}

The functional groups existing in the structures of the drug and the coformer are responsible for the formation of $\mathrm{CCs}$ through hydrogen bonds. In the formation of CCs of PPD with BA, the carboxylic acid moiety of BA and the nitrogen atom of piperidine group of PPD are involved in the formation of hydrogen bonds forming hetero synthon. CCs of PPD with PABA are formed between the amine group of PABA and carbonyl oxygen of PPD. There is another possibility of formation of hydrogen bonds between carboxylic acid of PABA and piperidine nitrogen of PPD molecule (45). 
The FTIR spectrum of the CCs showed a difference from that of the drug and coformers used. Shifts in the wave number indicate that the new molecular interactions influence the positions of the functional groups, as they are related to the wave numbers of the functional groups that participate in the formation of hydrogen bonds (46). SEM studies showed a change in the surface morphology of the CCs when compared to the drug, resulting in needle like and plate like CCs. From the DSC thermograms, the melting point of the $\mathrm{CCs}$ was found to be reduced when compared to the drug, which might be due to weaker interactions in the CCs. All these confirm the formation of CCs between the drug and the coformers used.

The angle of repose of the pure drug was $31.07 \pm 0.21^{\circ}$, while that of the CCs prepared using BA and PABA as coformers was $26.05 \pm 0.96^{\circ}$ and $27.64 \pm 0.99^{\circ}$ respectively. This indicates an improved flow of $\mathrm{CCs}$ when compared to pure PPD. Hausner's ratio of CCs of BA and PABA was obtained as $1.15 \pm 0.83$ and $1.11 \pm 0.82$ respectively when compared to $1.25 \pm 0.17$ in the case of pure drug. This indicates excellent flow characteristics. Carr's index values were $13.20 \pm 0.12$ and $10.52 \pm 0.41$ in case of CCs, when compared to that of $20.40 \pm 0.09$ as in case of PPD. This indicates good flowability of the CCs in comparison with the pure drug. The CCs exhibited an enhanced solubility and dissolution rate, which is assumed to be due to hydrogen bonded CCs, which dissociate quickly due to the weaker heteromolecular interactions in the CCs, leading to an enhanced dissolution rate in comparison with the drug (47). This might also be due to an increased affinity for the solvent and lowered interfacial barrier energy that generally occurs due to the formation of CCs. The coformer incorporation modifies the physical properties of drug. The aqueous solubilities of PPD-PABA CCs and PPD-BA CCs obtained by SE were enhanced 3.09- fold and 2.83- fold respectively. Literature review showed a solubility of PPD at $0.115 \mathrm{mg} / \mathrm{ml}$ in water and a 1.48 -fold increase in aqueous solubility of PPD CCs when prepared using boric acid as a conformer (19). The dissolution of the CCs is significantly enhanced when compared to the drug due to increased wettability and weaker associations $(48,49)$.

\section{CONCLUSION}

Pharmaceutical CCs of PPD were prepared with BA and PABA using the SE technique. The formation of CCs was confirmed by FTIR, DSC and XRD studies and supported by the SEM analysis. The prepared CCs exhibited higher solubility and dissolution compared with the pure drug. They also exhibited improved flow properties. Hence, cocrystals have proven to be an alternative strategy to overcome the solubility and dissolution problems of the poorly soluble PPD.

\section{ACKNOWLEDGEMENT}

The authors are thankful to Maharajah's College of Pharmacy, Vizianagaram, Andhra Pradesh and GITAM Institute of Pharmacy, GITAM Deemed to be University, Visakhapatnam, Andhra Pradesh for providing the facilities to carry out the research work. 


\section{ABBREVIATIONS}

BCS - Biopharmaceutical Classification System; PPD - Paliperidone; BA Benzoic acid; PABA - para-amino benzoic acid; CCs - cocrystals; NG - neat grinding; LAG - liquid assisted grinding; SE - solvent evaporation; FTIR - Fourier Transform Infrared Spectroscopy; DSC - Differential Scanning Calorimetry, SEM - Scanning Electron Microscopy; PXRD - Powder X-Ray Diffraction.

\section{REFERENCES}

1. Dolores RS, David W, Peter OC, Naila AM, Zelalem AW, Fransico BF et al. Optimising the in vitro and in vivo performance of oral cocrystal formulations via spray drying. European Journal of Pharmaceutics and Biopharmaceutics. 2018;124:13-27.

2. Blagden N, Matas M, Gavan PT, York P. Crystal engineering of active pharmaceutical ingredients to improve solubility and dissolution rates. Advanced Drug Delivery Reviews. 2007;59:617-630.

3. Abigail A, Jean RA, Pascal B, Harvey L. Modelling and prediction of cocrystal phase diagrams. International Journal of Pharmaceutics. 2009;374:82-89.

4. Changyan G, Haobin Z, Xiaochuan W, Jinjiang X, Yu L, Xiaofeng L et al. Crystal structure and explosive performance of a new CL-20/caprolactam cocrystal. Journal of Molecular Structure. 2013;1048:267-273.

5. Ning Q, Mingzhong L, Walkiria S, Naznee M, Angela D, Gary T. Pharmaceutical cocrystals: An overview. 2011;419:1-11.

6. Elena IK, Kratochvil B. Pharmaceutical cocrystals. Procedia Chemistry. 2014;10:473-476.

7. Dhara DB, Chetan HB. Spring and parachute: How cocrystals enhance solubility. Progress in Crystal Growth and Characterization of Materials. 2016;62:1-8.

8. Mohammad AM, Amjad A, Sitaram PV. Hansen solubility parameter as a tool to predict cocrystal formation. International Journal of Pharmaceutics. 2011;407:63-71.

9. Marisa R, Barbara B, Joao AL, Mafalda CS. Pharmaceutical cocrystallization techniques. Advances and challenges. International Journal of Pharmaceutics. 2018;547:404-420.

10. Gagniere E, Mangin D, Puel F, Rivoire A, Monnier O, Garcia E, Klein JP. Formation of cocrystals: Kinetic and thermodynamic aspects. Journal of Crystal Growth. 2009;311:2689-2695.

11. Rajesh T, Dinesh K, Rahul RC, Nalini RS. Multidrug co-crystals: towards the development of effective therapeutic hybrids. Drug Discovery Today. 2016;21(3):481-490.

12. Swetha K, Raju J, Prabhakar RV, Suresh B. Paliperidone loaded self-emulsifying drug delivery systems (SEDDS) for improved oral delivery. Journal of Dispersion Science and Technology. 2012;33:506-515.

13. Raj KM, Surendra G. Preparation and characterization of nanocrystals for solubility and dissolution rate enhancement of paliperidone using different hydrophilic carriers: In vitro in vivo study. Asian Journal of Pharmaceutical and Clinical Research. 2018;11(4):393-408.

14. Anuja P, Bhabagrahi R, Anil KD. Dissolution rate and bioavailability enhancement of co-ground mixtures of paliperidone, with different hydrophilic carriers. International Current Pharmaceutical Journal. 2013;2(3):70-77. 
15. Prabhakar D, Divya A, Pratyusha R, Shravan KK. Augmentation of dissolution profile of poorly soluble paliperidone by employing liquisolid technology. International Journal of PharmTech Research. 2014;6(2):710-719.

16. Sameer HL, Mangesh RB. Properties of solid dispersions of paliperidone in polyethylene glycol, comparison of solid-state properties, implementation of factorial design and dissolution behaviour. International Journal of Pharmacy and Biological Sciences. 2014;4(4):90-99.

17. Pandey A, Rath B, Dwivedi AK. Dissolution rate enhancement of BCS class II drug, Paliperidone by spray drying. Research Journal of Pharmaceutical, Biological and Chemical Sciences. 2013;4(2):145- 155.

18. Pandey A, Rath B, Dwivedi AK. Enhancement of dissolution rate and bioavailability of paliperidone by hot melt extrusion technique. Journal of Scientific \& Industrial Research. 2014;73:680-685.

19. Thimmasetty J, Ghosh T, Shashank NN, Raheem A. Oral bioavailability enhancement of Paliperidone by the use of cocrystallization and precipitation inhibition. Journal of Pharmaceutical Innovation. 2021;16(2):160-169.

20. Pawar A, Paradkar AR, Kadam SS, Mahadik KR. Effect of polymers on crystallo-coagglomeration of Ibuprofen-Paracetamol: Factorial design. Indian Journal of Pharmaceutical Sciences. 2007;69(5):658-664.

21. Tingting Z, Yan Y, Xiaojun Z, Jiangtao J, Hongmin S, Hongming H et al. Dissolution and pharmacokinetic properties of two paliperidone cocrystals with 4-hydroxybenzoic acid and 4amino benzoic acid. CrystEngComm. 2014;16:7667-7672.

22. David RW, Tanise S, Peddy V, Michael Z. Synthesis and structural characterization of cocrystals and pharmaceutical cocrystals: Mechanochemistry vs slow evaporation from solution. Crystal Growth \& Design. 2009;9(2):1106-1123.

23. Sawani GK, Sunil KJ, Abhay TS, Sadhika K, Sanjay KM. Multicomponent pharmaceutical adducts of eposartan: physicochemical properties and pharmacokinetics study. Crystal Growth and Design. 2017;17(4):1589-1599.

24. Anand A, Paul R, Amolkumar K, Ravindra H. Formulation and evaluation of buccal films of piroxicam co-crystals. Future Journal of Pharmaceutical Sciences. 2020;6:16.

25. Radha RE, Bharathi VV, Lakshmi UA, Bhavani AVS. Cross-linked chitosan based stomach specific mucoadhesive microspheres loaded with amoxicillin: Preparation and ex vivo characterization. Int. J. Pharm. Investigation. 2020;10(1):59-63.

26. Amjad A, Waseem K, Graham B, Hardyal G, Ali N, Sitaram PV. Theophylline cocrystals prepared by spray drying: Physicochemical properties and aerosolization performance. AAPS PharmSciTech. 2013;14(1):265-276.

27. Cecilia CP, Cristiane CM, Matheus SS, Luan FD, Renato JE. 5- fluorocytosine/5- fluorouracil drug-drug cocrystal: a new development route based on mechanical synthesis. Journal of Pharmaceutical Innovation. 2019;14:50-56.

28. Miranda LC, David RW, Ning S, Mazen H, Lukasz W, Michael JZ. Coformer selection in pharmaceutical cocrystal development: a case study of a Meloxicam aspirin cocrystal that exhibits enhanced solubility and pharmacokinetics. Journal of Pharmaceutical Sciences. 2011;100(6):21722181. 
29. Ravindra SD, Shailesh VB, Anant RP, Peter Y. Ultrasound assisted engineering of lactose crystals. Pharmaceutical Research. 2008;25(12):2835-2844.

30. Kevin CG, Jaydeep MP, Anjali PD, Abhay TD. Preparation and evaluation of agglomerated crystals by crystallo-co-agglomeration: An integrated approach of principal component analysis and Box-Behnken experimental design. International Journal of Pharmaceutics. 2013;452:135-156.

31. Prabhakar P, Giridhar S, Sarfaraj S, Pavan BR. Pharmaceutical Cocrystal of Piroxicam: Design, formulation and evaluation. Adv Pharm Bull. 2017;7(3):399-408.

32. Gaikwad ER, Khabade SS, Sutar TB, Santosh AP. Preparation and characterization of molecular complexes of fenofibrate cocrystal. Asian Journal of Pharmaceutics. 2017;11(4):745-759.

33. Prabhakar P, Giridhar S. Design and preparation of Zaltoprofen-Nicotinamide pharmaceutical cocrystals via liquid assisted grinding method. Indian Journal of Pharmaceutical Education and Research. 2019;54(4):563-570.

34. Ravindra SD, Adrian LK, Peter Y, Phil DC, Anant P. Cocrystallization and simultaneous agglomeration using melt extrusion. Pharmaceutical Research. 2010;27:2725-2733.

35. Santosh SC, Yatish RR, Anjali BT, Jaiprakash NS, Debarshi KM, Sanjay JK. Solvent drop grinding approach assisted development of glimepiride co-crystals: solubility enhancement journey of BCS class II product. Indian Journal of Pharmaceutical Education and Research. 2020;54(3):602-609.

36. Apurva JM, Grishma MP, Pragna KS, Anita NL. Development and characterization of thermosensitive intranasal gel containing paliperidone loaded microspheres. J Young Pharm. 2016;8(4):368-377.

37. Garbacz P, Wesolowski M. Benzodiazepine co-crystals screening using FTIR and Raman spectroscopy supported by differential scanning calorimetry. Spectrochimica Acta Part A: Molecular and Biomolecular Spectroscopy. 2020;234:118242.

38. Xiaohong P, Yilin Z, Rong Ch, Saif Q, Zhi Ch, Wenhua R et al. Cocrystal of sulfamethazine and pamino benzoic acid: structural establishment and enhanced antibacterial properties. Cryst. Growth Des. 2019;19:2455-2460.

39. Palash S, Rajesh GN, Khandavilli UBR, Ashwini N. Fast dissolving curcumin cocrystals, Crystal Growth \& Design. 2011;11:4135- 4145.

40. Braham D, Manjusha Ch, Vikas B. Preparation, characterization and evaluation of aspirin: benzoic acid cocrystals with enhanced pharmaceutical properties. Future Journal of Pharmaceutical Sciences. 2020;6:32.

41. Raju RT, Patond VB, Vaibhav SA, Prashant VA, Laxmikant NB, Nilesh MM et al. Preparation and characterization of co-crystals of diacerein. Indonesian J Pharm. 28(1):34-41.

42. Napada W, Manop Ch. Application of Box-Behnken design for processing of mefenamic acidparacetamol cocrystals using gas anti-solvent process. Journal of $\mathrm{CO}_{2}$ utilization. 2018;26:212-220.

43. Rehem AK, Yacoub AB, Aly N. Dissolution enhancement of atorvastatin calcium by cocrystallization. Advanced Pharmaceutical Bulletin. 2019;9(4):559-570.

44. Fang L, Ling YW, Ming CY, Yan TL, Zhi YW, Cui WY. A new cocrystal of isoniazid-quercetin with hepatoprotective effect: The design, structure and in vitro/ in vivo performance evaluation. European Journal of Pharmaceutical Sciences. 2020;144:105216. 
45. Madhukar H, Wan SL, Ching KQ, Hoong KF. Investigation of supramolecular synthons and structural characterization of aminopyridine-carboxylic acid derivatives. Chemistry Central Journal. 2014;8:31.

46. Jianle Z, Liang L, Hailu Z, Jiangping X, Dandan H, Ningbo G et al. Crystal structures, dissolution and pharmacokinetic study on novel phosphodiesterase-4 inhibitor chlorbipram cocrystals. International Journal of Pharmaceutics. 2020;576:118984.

47. Anastasiya VM, Svetlana AM, Natalia VB, Konstantin BG, Svetlana AK, Tatyana PS. Screening and characterization of cocrystal formation between botulin and terephthalic acid. Materials Today: Proceedings. 2020;25(3):381-383.

48. Amol S, Srinivasa M, Bhagyashri T, Adhikrao Y, Sachin S, Sfurti S, Rajendra D. Studies on effect of hydrophilic polymers on physicochemical properties of itraconazole cocrystals. Future Journal of Pharmaceutical sciences. 2017;3:95-102.

49. Perlovich GL, Manin AN. Design of pharmaceutical cocrystals for drug solubility improvement. Russian Journal of General Chemistry. 2014;84(2): 407-414. 


\title{
Dobijanje kokristala paliperidona sa poboljšanom rastvorljivošću i brzinom rastvaranja
}

\author{
Earle Radha Rani ${ }^{1,2 *}$ Gadela Venkata Radha $^{2}$ \\ ${ }^{1}$ Maharajah's College of Pharmacy, Vizianagaram, Andhra Pradesh, India \\ ${ }^{2}$ GITAM Institute of Pharmacy, GITAM Deemed to be University, Visakhapatnam, \\ Andhra Pradesh, India \\ *Autor za korespondenciju: Earle Radha Rani, E-mail: radhaearle@yahoo.com
}

\section{Kratak sadržaj}

U ovom istraživanju, kokristali (CCs) paliperidona (PPD) sa koformerima kao što su benzojeva kiselina (BA) i p-aminobenzojeva kiselina (PABA) sintetisani su, i okarakterisana su poboljšanja njihovih fizičko-hemijskih svojstava i brzine rastvaranja. Kokristali su pripremljeni postupkom isparavanja rastvarača (SE) i upoređeni su sa proizvodima dobijenim postupkom suvog (NG) i vlažnog mlevenja (LAG) u pogledu poboljšanja rastvorljivosti. Formiranje kokristala je potvrđeno metodama infracrvene spektroskopije, rendgenske difrakcije na prahu i termalne analize. Ispitivanja rastvorljivosti ukazuju na to da je rastvorljivost kokristala PPD-BA

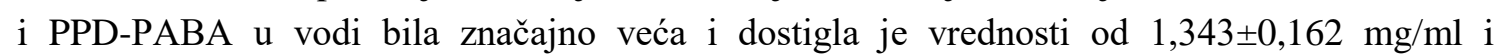
$1,964 \pm 0,452 \mathrm{mg} / \mathrm{ml}$, u poređenju sa rastvorljivošću PPD koja iznosi $0,473 \mathrm{mg} / \mathrm{ml}$. To znači da je rastvorljivost povećana 2,83, odnosno 3,09 puta. Za PPD je uočena niska brzina rastvaranja od $37,8 \%$ za 60 min, dok se brzina rastvaranja kokristala znatno povećala do 96,07\% i 89,65\% za 60 min. Kokristali PPD sa BA i PABA predstavljaju savremeni pristup u prevazilaženju izazova vezanih za rastvorljivost slabo rastvorljive lekovite supstance PPD.

Keywords: paliperidon, kokristali, koformer, rastvorljivost, brzina rastvaranja 